\title{
Teaching Video NeuroImages: Marcus-Gunn pupil in tuberous sclerosis
}

\author{
Jaime Toro, MD, FAAN, FACP, and Jorge Patiño, MD
}

Neurology ${ }^{\circledR}$ 2018;91:e694-e695. doi:10.1212/WNL.0000000000006005

\section{Correspondence}

Dr. Toro

jtoro@uniandes.edu.co

Figure 1 Funduscopy and optical coherence tomography (OCT)

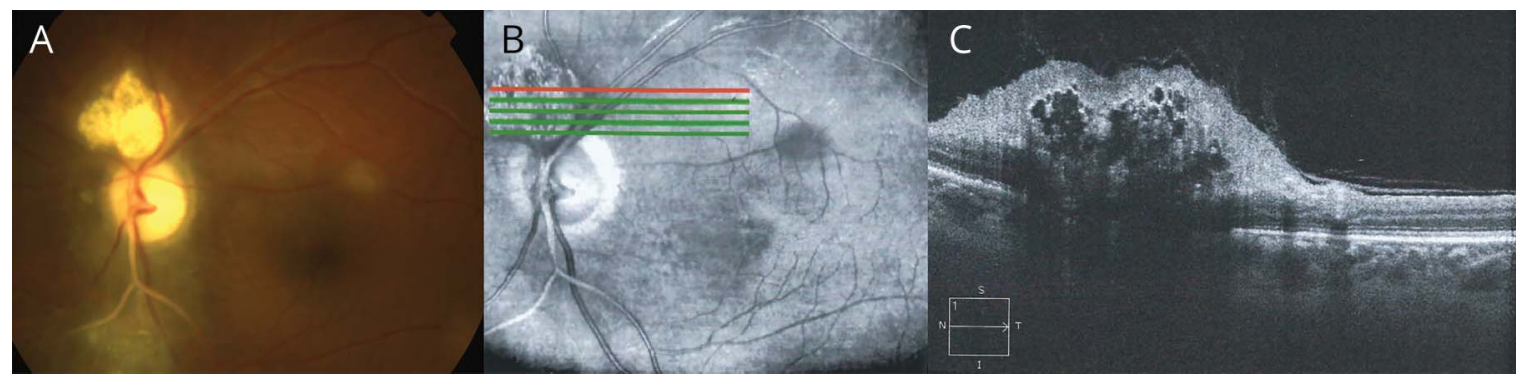

Funduscopy (A) of the left eye and OCT (B, C) show a well-demarcated lesion with intralesional cysts, located in the superior border of the left optic nerve and compatible with a retinal hamartoma.

A 22-year-old woman with tuberous sclerosis (TS) and an incomplete resection of a leftsided astrocytoma presented with a 4-year history of visual deterioration. Neurologic examination revealed a left relative afferent pupillary defect (RAPD) (video) with a pale left optic disc. Visual acuity was $20 / 100$ bilaterally and a left-sided superior visual field loss was seen. Optical coherence tomography showed a left retinal hamartoma (figure 1). Contrast-enhanced brain MRI showed bilateral cortical and subcortical tubers (figure 2). Marcus-Gunn pupil or RAPD is a nonspecific feature denoting optic neuropathy. ${ }^{1}$ TS ophthalmopathy includes retinal and iris hamartomas, choroid colobomas, and hypopigmented lesions on iris and ciliary body. ${ }^{2}$

\section{MORE ONLINE}

○ Video

\section{$\rightarrow$ Teaching slides}

links.lww.com/WNL/ A631

Figure 2 T2-weighted and fluid-attenuated inversion recovery (FLAIR) MRI
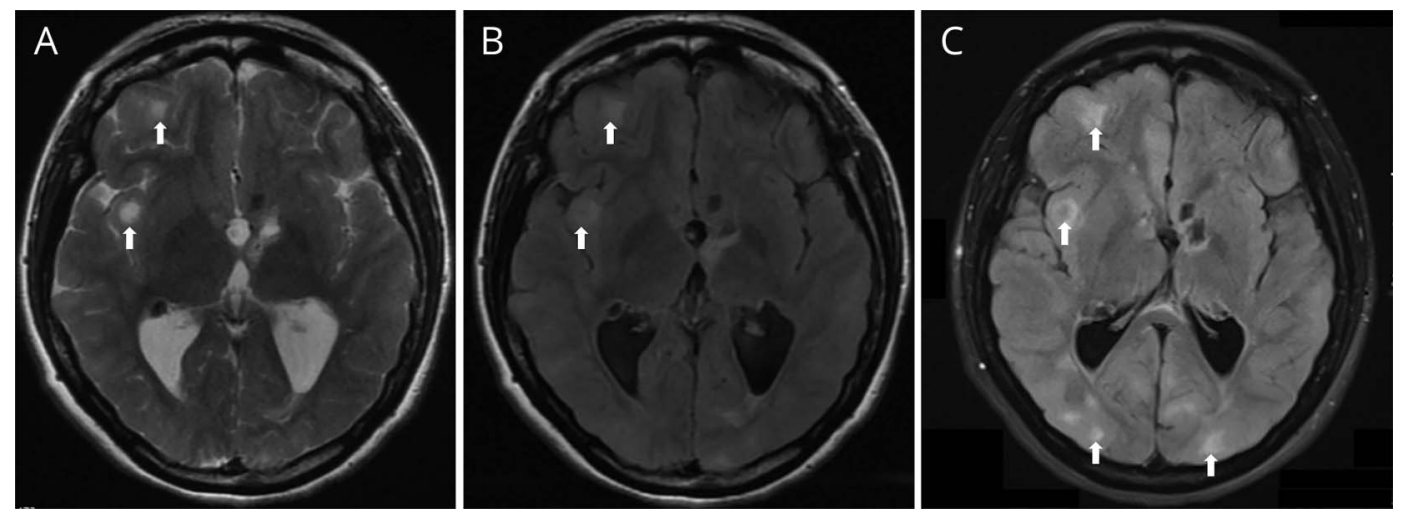

T2-weighted (A) and FLAIR (B, C) MRI show cortical and subcortical tubers (arrows).

From the Hospital Universitario-Fundación Santa Fe de Bogotá (J.T., J.P.); School of Medicine (J.T.), Universidad El Bosque; and School of Medicine (J.T.), Universidad de Los Andes, Bogotá, Colombia.

Go to Neurology.org/N for full disclosures. Funding information and disclosures deemed relevant by the authors, if any, are provided at the end of the article.

Copyright (c) 2018 American Academy of Neurology. Unauthorized reproduction of this article is prohibited. 


\section{Author contributions}

Dr. Toro contributed to the composition of the manuscript and acquisition of the multimedia material. Dr. Patiño contributed to the composition of the manuscript and acquisition of the multimedia material.

\section{Study funding}

No targeted funding reported.

\section{Disclosure}

J. Toro is an Associate Editor for the New England Journal of Medicine Journal Watch Neurology and has served on this board since 1999. He receives honoraria from the journal. Dr. Toro has been a board member of Multiple Sclerosis and Related Disorders Journal since 2012. He does not receive honoraria from this journal. J. Patiño reports no disclosures relevant to the manuscript. Go to Neurology.org/ $\mathrm{N}$ for full disclosures.

\section{References}

1. Pearce J. The Marcus Gunn pupil. J Neurol Neurosurg Psychiatry 1996;61: 520.

2. Robertson DM. Ophthalmic manifestations of tuberous sclerosis. Ann NY Acad Sci 1991;615:17-25. 


\title{
Neurology
}

\author{
Teaching Video NeuroImages: Marcus-Gunn pupil in tuberous sclerosis \\ Jaime Toro and Jorge Patiño \\ Neurology 2018;91;e694-e695 \\ DOI 10.1212/WNL.0000000000006005
}

This information is current as of August 13, 2018

\section{Updated Information \& Services}

References

Subspecialty Collections

Permissions \& Licensing

Reprints including high resolution figures, can be found at: http://n.neurology.org/content/91/7/e694.full

This article cites 2 articles, 1 of which you can access for free at: http://n.neurology.org/content/91/7/e694.full\#ref-list-1

This article, along with others on similar topics, appears in the following collection(s):

Clinical neurology examination

http://n.neurology.org/cgi/collection/clinical_neurology_examination MRI

http://n.neurology.org/cgi/collection/mri

Optic nerve

http://n.neurology.org/cgi/collection/optic nerve

Other neurocutaneous disorders

http://n.neurology.org/cgi/collection/other_neurocutaneous_disorders

Pupils

http://n.neurology.org/cgi/collection/pupils

Information about reproducing this article in parts (figures,tables) or in its entirety can be found online at:

http://www.neurology.org/about/about_the_journal\#permissions

Information about ordering reprints can be found online:

http://n.neurology.org/subscribers/advertise

Neurology ${ }^{\circledR}$ is the official journal of the American Academy of Neurology. Published continuously since 1951, it is now a weekly with 48 issues per year. Copyright (O) 2018 American Academy of Neurology. All rights reserved. Print ISSN: 0028-3878. Online ISSN: 1526-632X.

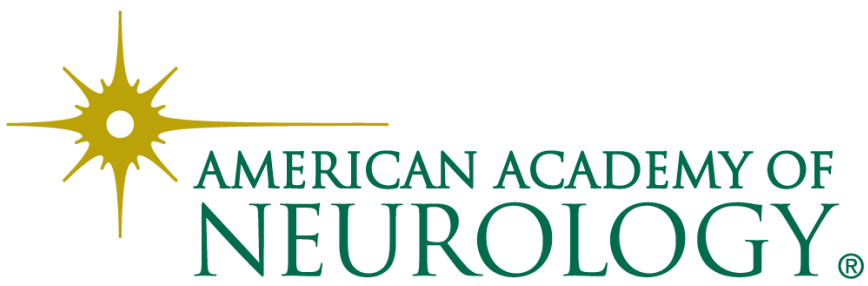

